If colke is used in the stoves there is no trouble with soot in the economisers, such as was found here with economisers used in connection with ordinary coal-stoked room fires. The stove economisers here require to be cleaned only once a year, principally for dust.

When the Government undertook the control of coal, plans and descriptions of the above economisers were sent to the Controller of Coal Mines.

Ardenlea, Falkirk, December 27, I9I8.

John Aitken.

\section{University Poverty or Parsimony?}

SHortly before the war broke out there was some correspondence, in NATURE and elsewhere, with reference to the pay offered to chemists in advertisements of the Research Department of Woolwich Arsenal. Exception was taken to the offer of little more than rool. a year to men who were supposed to have received training rendering them competent to undertake research work. As a result, I believe, the Department was led to attach a rate of pay to the posts not quite so inadequate as that first proposed.

Apparently during the war some slight conception of the value of chemistry to the nation has been forced upon the public. So much has been said about the importance of research that we are almost as willing as the Americans to "talk big" about it, and put emphasis upon the first syllable. We even recognise (on paper) an indissoluble connection between science and industry; in fact, so great is our advance that several literary men have been appointed, at high salaries, to supervise the expenditure of public funds on technical scientific inquiries. It is true the Board of Trade has systematically declined to associate science with the dyestuff industry, but only by way of being the exception to prove the rule. The Board, we know, is a superior body, and not to be led by any vulgar policy; the highest explosives would not cause its august officials to accept advice.

The President of the Board of Education, too, has often discoursed eloquently on the value of intelligence; moreover, the need of attracting intelligence, if not genius, into the chemical and other learned careers is a topic we never, weary of airing in these days.

My object now is to direct attention to the way in which the learned are living up to their own professions, to urge that charity really should begin at home. I do this because my eye has casually fallen upon an advertisement in your columns in which applications are invited by the Vice-Chancellor of the University of London for a University chair of chemistry tenable at King's College at the princely salary of $600 l$. a year. Thus do we testify to our belief in ourselves. No man can fulfil the duties of such a chair adequately on such pay.

It can only be supposed that the University desires to write down the value of King's College chemistry in comparison with that taught at the South Kensington and University Colleges. A more effective way could not well be found, and in the interest of the subject it would undoubtedly be better to concentrate the teaching at two schools.

If, however, chemistry be retained in existence in the Strand, and funds be not forthcoming for the proper endowment of a chair, at most a lectureship should be established; and it would be wise to provide that candidates should not exceed about twentyfive years of age and should hold the appointment at most during ten years.

Let us hope that the profession will make no response to the invitation. Unless chemists themselves take some effective action to protect their interests, the position of chemical science in this country will not NO. 2566 , VOL. IO2] only be worse than it was before the war, but must steadily degenerate as years go on.

Henry E. Armstrong.

\section{Inter-Allied Conference on International Organisations in Science.}

IN the account of the Inter-Allied Scientific Conference at Paris published in NATURE of December 26 , reference ought, perhaps, to have been made to the status which it has been decided to give to the selfgoverning British Dominions. These will be able to join any international association under the proposed scheme, on signifying their intention to do so, with the same voting power as independent States.

Arthur Schuster.

Yeldall, Twyford, Berks, December 27, 1918.

\section{SCIENTIFIC RESEARCH AND \\ PREVENTIVE MEDICINE.}

$\mathrm{T}$ was stated recently in these columns that the toll of pain and death due to causes which are more or less preventable may be gauged in terms comparable with those demanded by the sufferings directly attributable to war. In order to reduce such sources of national loss it was considered important that in the evolution of schemes tor the furtherance of research work in pure and applied science the question of the encouragement of research work in all branches of medical science should occupy a prominent place. The pandemic of influenza recently experienced may be taken as an illustration of the need for wide-embracing and well-organised research work in preventive medicine, and particularly in epidemiology. That such an epidemic would well deserve thorough and extensive investigation seems self-evident. According to the medical correspondent to the Times of December 18 and 19 , I9I8, there is good reason to estimate the world's death-roll from influenza and pneumonia at not fewer than 6,000,000 lives, at which rate he points out that this epidemic has been five times as deadly as the war during the same period of three months. Now a visitation on such a scale as this, in which many of the victims are in the prime of their lives, is comparable with the great plagues of the Middle Ages, and, coming at such a time as the present, is catastrophic from whatever point of view it may be regarded.

Epidemics of influenza have recurred at intervals for some hundreds of years, and in recent times have fallen on us in $1803,1833,1837-38$, $1847-48$, and 1889 , when it became annual for several years. From 1860 to 1889 the disease became practically extinct the mortality per rooo being about $0^{\circ} 003$. Even during these epidemics the case mortality was low when compared with that which has obtained in the present outbreak, and was estimated at $I$ to $I^{\cdot} 6$ per 1 ooo. One of the most remarkable features of the recent epidemic is the tendency to the development of very acute toxic symptoms with such astounding rapidity that the body of the victim is overcome by the poison before defences can be put up; ip any case, the defence is of a very temporary 